${ }^{\circ}$ Entomologica Fennica. 27 June 1995

\title{
Invertebrate fauna of Norway spruce (Picea abies) saplings and its connection with the nitrogen, sulphur and phenolics concentration of the needles
}

\author{
Anne Laine, Juhani Itämies, Markku Orell \& Sisko Kvist
}

Laine, A., Itämies, J., Orell, M. \& Kvist, S. 1995: Invertebrate fauna of Norway spruce (Picea abies) saplings and its connection with the nitrogen, sulphur and phenolics concentration of the needles. - Entomol. Fennica 5:177-185.

The composition of the invertebrate fauna living on young Norway spruce (Picea abies) branches was studied in northern Finland both in urban and rural areas during the summer months of 1988. Attention was given to the total nitrogen, sulphur and phenolics concentration of the needles. The material consisted of 52627 invertebrates from 300 separate spruce saplings. Mites formed the majority of the invertebrates. Most numerous were Ameronothrus dubinini, Diapterobates humeralis and Ceratoppia bipilis. Springtails and spiders were also numerous. The invertebrate abundances were highest in the urban areas of Isko and Linnanmaa, where the sulphur and nitrogen concentration of the needles was high and the phenolics/nitrogen ratio low. The lowest invertebrate abundances were found in Rusko, the most urban area, and Taivalkoski, the most rural area. Nitrogen and sulphur concentrations were highest at Rusko and lowest at Taivalkoski. Possible reasons for the results are discussed.

Anne Laine, Juhani Itämies, Markku Orell \& Sisko Kvist, Department of Zoology, University of Oulu, P.O.Box 333, FIN-90571 Oulu, Finland

Received 20 June 1993, accepted 1 March 1994

\section{Introduction}

The effects of air impurities on conifers have been widely studied, and the usually positive influence of the impurities upon the invertebrate fauna living on the trees is well known (see e.g. McNeill \& Whittaker 1990). The role of invertebrates may be important in the forest decline syndrome (Katayev et al. 1983, Führer 1985, Opperman 1985, Hain 1987). Studies have mostly been made on aphids, beetles or moths, which can be regarded as pests (Flückiger \& Oertli
1978, Villemant 1981, Braun \& Flückiger 1984, Dohmen et al. 1984, Dohmen 1985, Opperman 1985, Heliövaara 1986, Heliövaara \& Väisänen 1986, Neuvonen et al. 1987, Holopainen et al. 1993, Kainulainen et al. 1993).

In several of the studies it has been found that an increase in sulphuric compounds or toxic metals in the air has been followed by an increase in pest numbers. One possible explanation is a physiological change in the host plant, as proposed by Alstad et al. (1982), Führer (1985) and Warrington (1987). Variability in secondary compounds, 


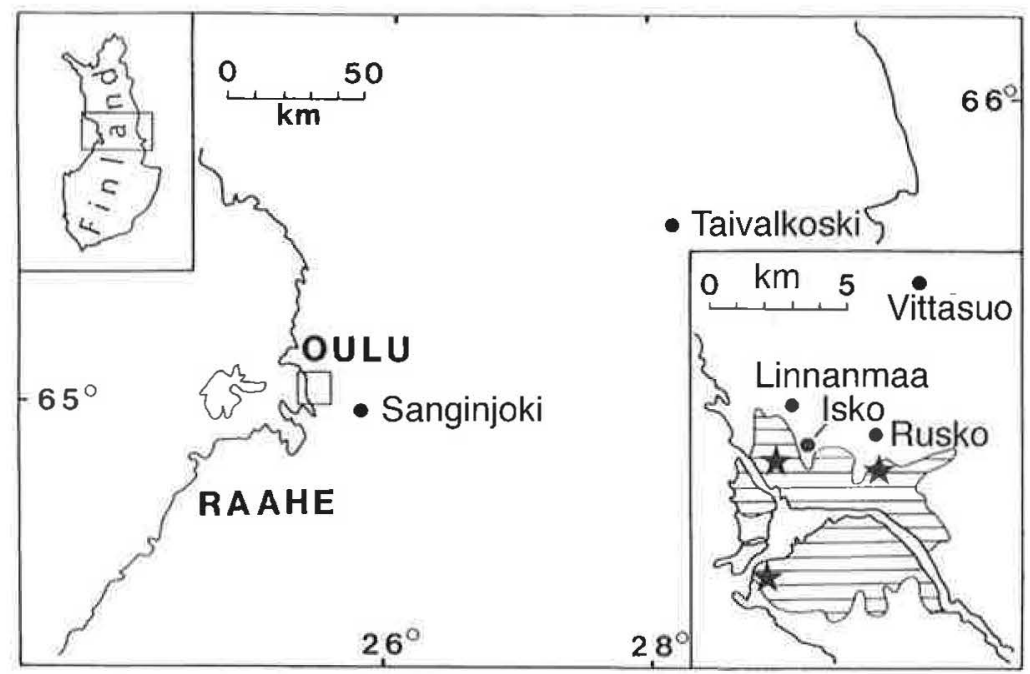

Fig. 1. The research areas: Rusko (Grid $27^{\circ} \mathrm{E} ; 721: 43$ ), Isko (721:42), Linnanmaa (721:42), Vittasuo (722:43), Sanginjoki (721:44), and Taivalkoski (727:56). Major pollution sources are represented by stars. Prevailing winds in the area are $\mathrm{W}$, SW, spreading air impurities of the industrial cities of Oulu (pulp and fertiliser industry) and Raahe (iron and steel works) mostly eastwards. e.g. phenols and tannins, and nutrients, e.g. nitrogen, has been assumed to constitute an important factor in plant-herbivore interactions (Jensen 1988). This system is, however, a complex one with many interacting factors. The relation between e.g. the nitrogen concentration of the needles and the abundance of certain herbivores is thus difficult to establish (Alstad et al. (1982). Certain changes in amino acid composition and concentrations may, however, benefit herbivorous insects and so increase their numbers (Brodbeck \& Strong 1987, Kidd et al. 1990). If at the same time parasites suffer from pollution as shown by Alstad et al. (1982; see, however, Holopainen et al. 1993) the increase will be even stronger. Larsson (1989) studied a pattern where insects with different feeding habits responded differently to stressed trees: the feeding guild should be considered.

In this paper we present results from a study on the composition of the invertebrate fauna living on young Norway spruce (Picea abies) branches in northern Finland in both urban and rural areas, and on the total nitrogen, sulphur and phenolics concentrations of the needles.

\section{Material and methods}

The study sites were situated at different distances from the city of Oulu which is close to the coast of the Bothnian Bay, in northern Finland (Fig. 1), where the prevailing winds are W to SW spreading air impurities from the industrial cities of Oulu and Raahe inland. Three of the study sites (Rusko, Isko, and Linnanmaa) are located within the urban area of Oulu, two (Vittasuo and Sanginjoki) in the neighbouring countryside and one (Taivalkoski) inland. Fully comparable study areas were hard to find. None of the areas was a pure sapling stand; young trees grew among older trees, both conifers (spruce and pine) and deciduous trees (mostly birch, willows and a minority of rowans) were always present.

The main pollution sources in the Oulu and Raahe area are pulp and fertiliser factories, iron and steel works, heat power stations and traffic. The local sulphur fallout per year is $400 \mathrm{mg} \mathrm{S} / \mathrm{m}^{2}$ in the Oulu area, $100-200 \mathrm{mg} \mathrm{S} / \mathrm{m}^{2}$ on the rural area surrounding it and $50-100 \mathrm{mg} \mathrm{S} / \mathrm{m}^{2}$ in the Taivalkoski area (Anon. 1986, Pietilä et al. 1990).

The Rusko study area was a dense wood situated near the fertiliser factories of Kemira and close to a road with heavy traffic. The wood at Isko, with numerous young and old spruces and only a minority of deciduous trees, was situated near a motorway. By its appearance the study area of Linnanmaa was quite similar to the area of Rusko, with a variety of different tree species. It was, however, not as dense and the ground was more boggy. Vittasuo and Sanginjoki were quite similar to each other, with some young trees in 
an older mixed forest. Taivalkoski was the purest sapling stand with only a few old trees, mostly birches.

At each study area 10 samples were collected once a month during May to September in 1988. One sample consisted of 3-4 branches of a 2-3 $\mathrm{m}$ high spruce sapling. The branches were cut at different heights on the southern side of the tree and put in a plastic bag. In the laboratory the branches were cut into smaller pieces and the macroscopic invertebrates were collected. The branch material was kept in extracting cylinders for 2-3 weeks. After drying the needles and twigs were weighed. Inverterbrate abundances were calculated (index $=$ number of specimens per $1000 \mathrm{~g}$ dry weight of total branch material). The material consisted of 300 separate spruce saplings, their total dry weight being $28.4 \mathrm{~kg}$.

Separate needle samples from all the saplings studied were collected for nitrogen, sulphur and phenolic analyses. The samples were kept in a deep-freeze $\left(-20^{\circ} \mathrm{C}\right)$ until they were handled. The shoots of the previous year (1987) were cut and dried in $+60^{\circ} \mathrm{C}$ for 24 hours. Total sulphur and nitrogen concentrations of the dried and powdered needles were determined at the laboratory of Kemira in Oulu. The sulphur concentration was analysed using Leco, and nitrogen using Kjelldahl analysers. The total phenolic concen- tration was measured using the Folin-Dennis method (Swain \& Hilles 1956, Burns 1963) modified for spruce needles.

\section{Results}

\subsection{The branch material}

Although the height of the trees did not differ between areas, with the exception of Sanginjoki (Table 1, Duncan's test), the branches of Taivalkoski spruces were significantly larger than the branches of the urban area (1-3) spruces.

The mean values of total nitrogen and sulphur were highest in the urban areas, decreasing towards the rural areas (Table 1). The phenolics/ nitrogen ratio was decreasing towards the urban areas with a significant difference between urban and other areas. The sulphur and nitrogen concentrations of the needles were lowest in June, and increased towards September in each of the study areas (Fig. 2). The phenolics concentration reached its maximum in July. The phenolics/ nitrogen ratio was at its highest in June-July. In the early summer there were only small differences between the areas, but in the late summer the ratio was significantly higher in the rural areas (4-6) than in the urban areas (1-3, Fig. 2).

Table 1. The spruce branch material of the study areas (Rusko, Isko, Linnanmaa, Vittasuo, Sanginjoki, Taivalkoski, see Fig. 1). Dry weight and concentrations of total sulphur, nitrogen and phenolics are indicated by the mean of each study area. Invertebrate abundance refers to the number of invertebrates per $1000 \mathrm{~g}$ of dry branch material. Results of Anova are given. Duncan's multiple range test shows the areas which significantly ( $P$ $<0.001$ ) deviate from each other (initial letters separated by a diagonal mark) with respect to the variable in question. The farther the symbol the greater the difference. When testing invertebrate numbers total numbers were concerned with the dry weight of the branch serving as covariate.

\begin{tabular}{|c|c|c|c|c|c|c|c|c|}
\hline & \multicolumn{3}{|c|}{ Urban areas } & \multicolumn{3}{|c|}{ Rural areas } & \multirow[b]{2}{*}{$F_{5270}$} & \multirow[b]{2}{*}{ Duncan's } \\
\hline & Rusko & Isko & Linnansuo & Vittasuo & Sanginjoki & Taivalkoski & & \\
\hline Number of samples & 50 & 50 & 50 & 50 & 50 & 50 & & \\
\hline Sapling height, $m$ & 2.35 & 2.40 & 2.30 & 2.45 & 2.75 & 2.35 & 4.82 & S/VITRL. \\
\hline Branch dry weight, g & 86 & 84 & 86 & 102 & 97 & 113 & 8.11 & $\mathrm{~T} / \mathrm{IRL}$ \\
\hline Total sulphur, mg/g & 0.880 & 0.877 & 0.863 & 0.737 & 0.717 & 0.623 & 16.87 & LIR/NS/T \\
\hline Total nitrogen, $\mathrm{mg} / \mathrm{g}$ & 12.173 & 11.967 & 10.800 & 10.337 & 9.663 & 9.064 & 21.50 & $\mathrm{RI} / \mathrm{LV} / \mathrm{ST}$ \\
\hline Total phenols, $\mathrm{mg} / \mathrm{g}$ & 59.494 & 55.176 & 47.360 & 60.080 & 54.886 & 60.090 & 16.66 & TVR/IS/L \\
\hline Phenolics/nitrogen & 4.89 & 4.54 & 4.22 & 5.87 & 5.81 & 6.41 & 12.15 & TVS/RIL \\
\hline Sum of invertebrates & 5743 & 12184 & 12162 & 8286 & 8720 & 5532 & 19.01 & IL/SV/RT \\
\hline Invertebrate abundance & 1441 & 3110 & 3081 & 1778 & 1997 & 834 & & \\
\hline
\end{tabular}



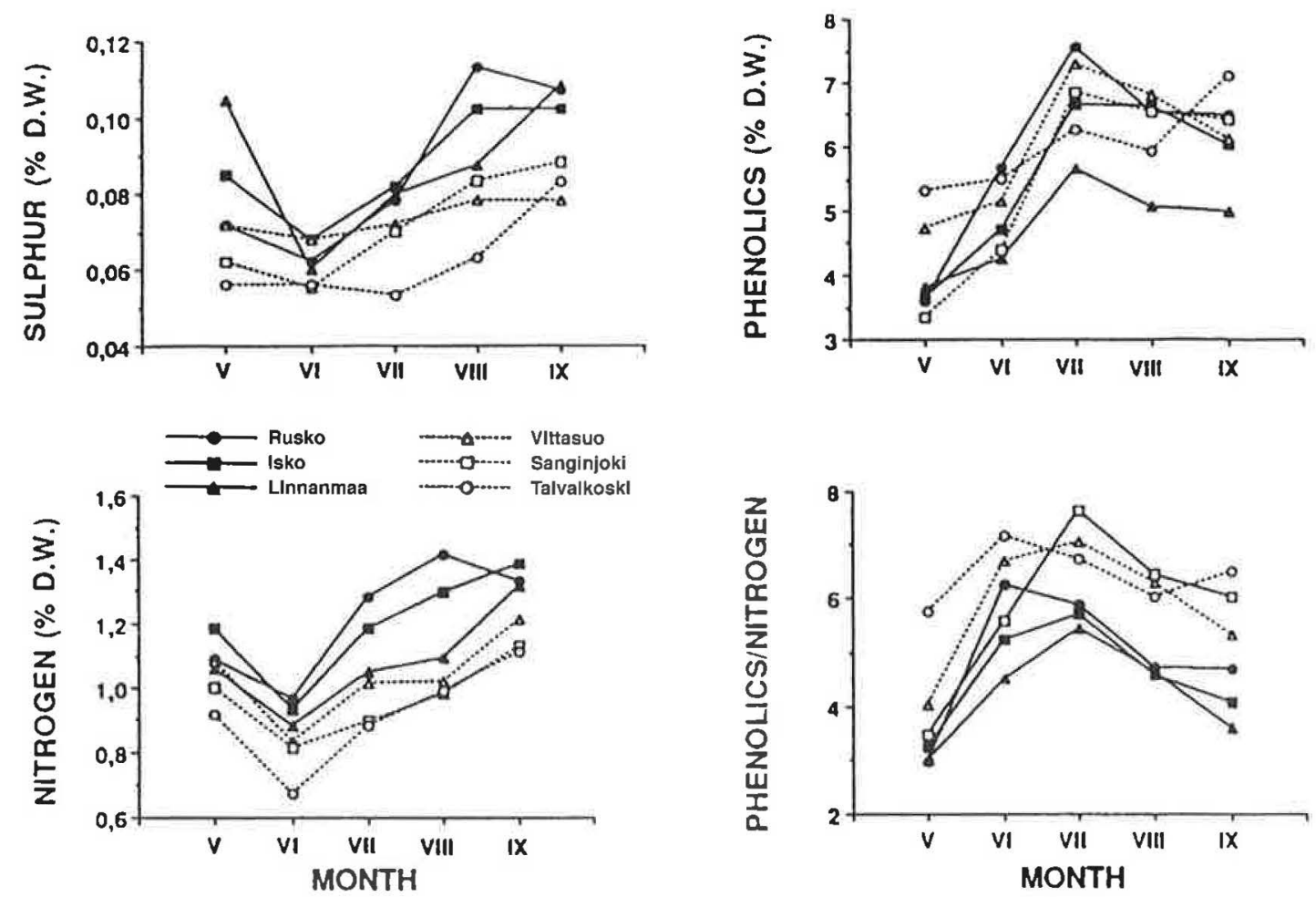

Fig. 2. Monthly concentration of total sulphur, nitrogen and phenolics and phenolics/nitrogen ratio in the needles of the study areas (see Fig. 1).

\subsection{Invertebrates}

Altogether 52627 invertebrates were caught during this study (average of 175 individuals per sample, and 1429 individuals per $1 \mathrm{~kg}$ dry weight of branch material). According to Duncan's multiple range test Isko, which had the highest animal numbers, and Linnanmaa deviated significantly from Sanginjoki and Vittasuo, and especially from Rusko and Taivalkoski where the animal numbers were lowest (Table 1). The animal abundances were highest in August (Fig. 3).

Mites formed the majority of the herbivorous group (Table 2). Most numerous were Ameronothrus dubinini, Diapterobates humeralis and Ceratoppia bipilis. A. dubinini and C. bipilis were most frequent in urban areas. The between area differences were statistically significant in the herbivore group and also in carnivores and parasites. There were no between area differences in the total number of omnivores and decomposers.

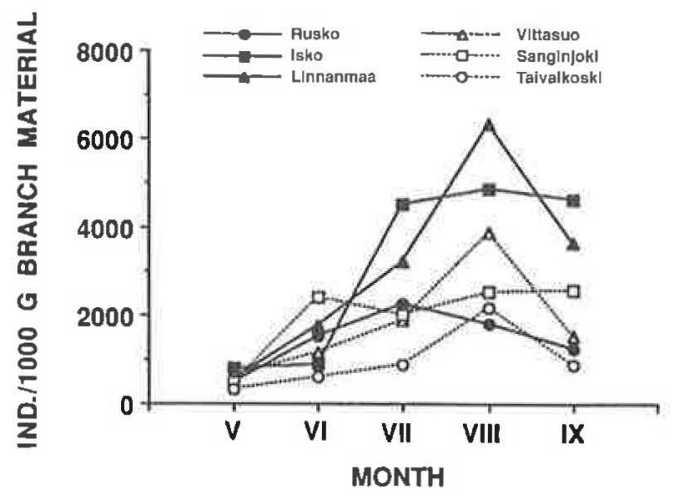

Fig. 3. The mean abundances (ind./1000 g branch material) of the monthly invertebrate numbers at the study areas (see Fig. 1).

Accidentals, which consisted mostly of nematocerans, were most numerous at Rusko (Table 2).

The herbivore abundance seemed to increase, although not significantly, with increasing sulphur and nitrogen concentration in the needles 

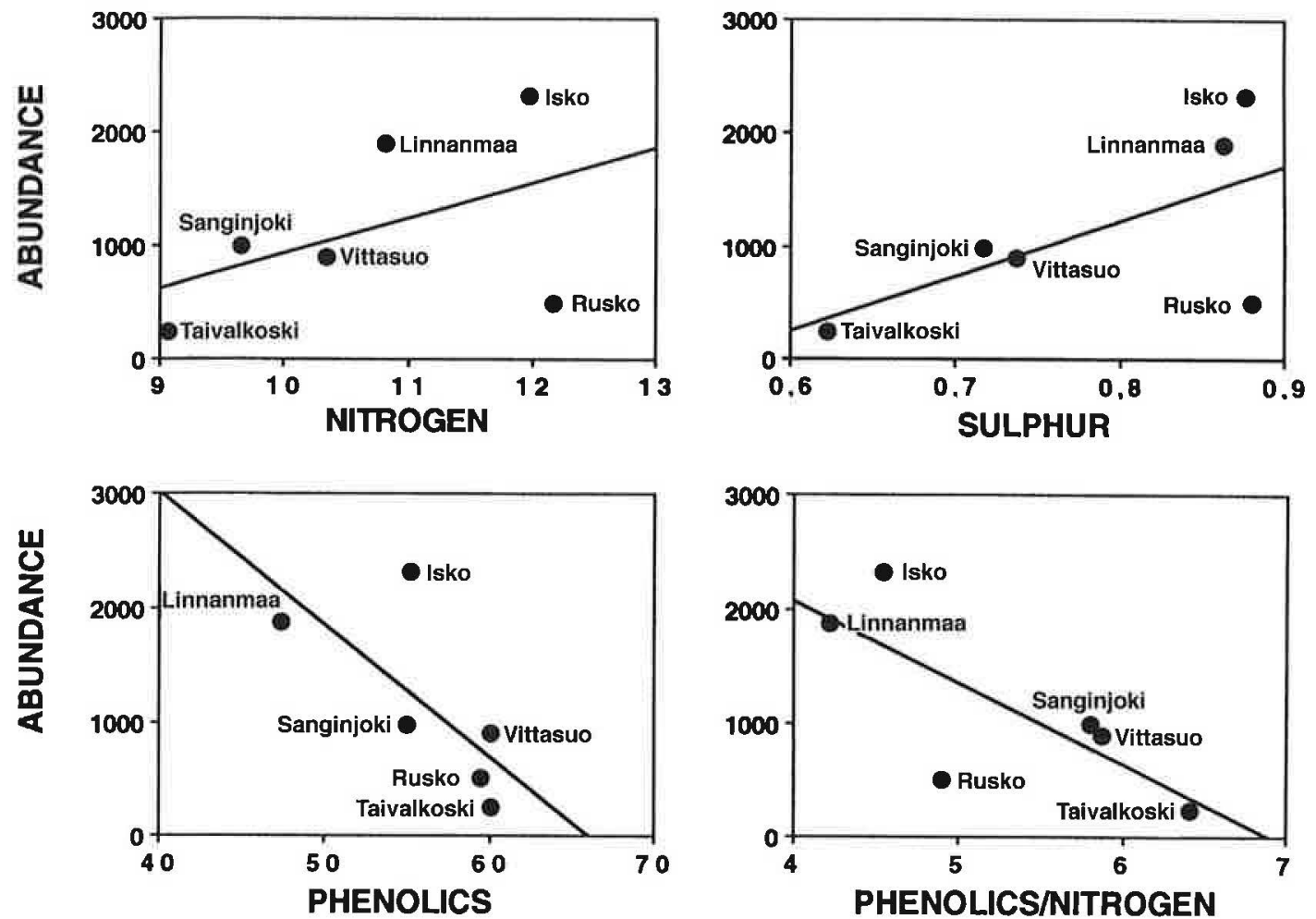

Fig. 4. Mean summertime herbivore abundances plotted against total nitrogen, sulphur and phenolics concentrations $(\mathrm{mg} / \mathrm{g})$ and the phenolics/nitrogen ratio in the needles of the study areas (see Fig. 1).

(Fig. 4). Rusko, however, deviated from the general trend. The herbivore abundance was highest in the urban areas of Isko and Linnanmaa where the phenolics/nitrogen ratio of the needles was the lowest.

\section{Discussion}

In northern Finland long range emissions are still at a rather low level (Tuovinen 1989). The yearly sulphur fallout of foreign origin varies from 300 to $500 \mathrm{mg} \mathrm{S} / \mathrm{m}^{2}$ per year in a north-south direction (Anon. 1986).

The invertebrate numbers found in this study were generally highest in the most urban areas, which were characterized by elevated nitrogen and sulphur levels in the spruce needles. The same trend was also seen in old spruce branches in the same area (Laine et al. 1990). The between area differences were significant in spite of the fact that the needles of coniferous trees do not show rising concentrations of e.g. sulphur as clearly as for example moss or lichens (Lamppu 1989). The increase in total animal numbers was mostly caused by a huge increase in the numbers of certain mite species, e.g. Diapterobates humeralis and Ceratoppia bipilis. In the most rural area, Taivalkoski, the invertebrate numbers were smallest, and both the sulphur and nitrogen concentrations of the needles were lowest. Geographical factors may, however, be involved as this area lies inland. Rusko formed an exception: total nitrogen and sulphur concentrations reached their maximum, and the number of herbivores in particular was very low. It may represent the phase where the increase in various substances has turned toxic (cf. Heliövaara \& Väisänen 1990 and Mattson \& Witter 1990). The response of different, closely related species of aphids to pollution seems to be variable, according to Holopainen et al. (1993). 
When the sulphuric acid concentration grows too high its effects become toxic (Warrington 1987). The long term effects of sulphur often result in a lowered level of organic material and in a weakened general tolerance in coniferous trees (Knabe 1976). As air impurities cause either structural damage or a change in vital activities (Kramer \& Kozlowski 1979) the damaged trees are not as capable of transporting assimilation products for growth as healthy trees are. In our material the percentage of needle dry weight diminished towards the urban areas, being highest in Taivalkoski and lowest in Rusko. A similar trend has been observed in the needles of Scots pine (Pinus sylvestris, Heliövaara \& Väisänen 1990). On the other hand the invertebrate numbers in practically all of the nutritional groups were lowest in the most rural area.

The numbers of herbivores were extremely high in most urban areas. As air pollutants can change the biochemistry and physiology of the host plant, they may increase its palatability to herbivores (Warrington 1987, Kainulainen et al. 1993) or weaken its resistance against them (Katayev et al. 1983, Braun \& Flückiger 1984, Führer 1985). This mode of action is still, however, poorly known (Hain 1987). The feeding guild of insect species has an important effect upon the occurrence of the species on trees under stress (Larsson 1989). Pietilä et al. (1990) found the level of total proteins in bilberry (Vaccinium myrtillus) higher in a nitrogen polluted industrial area than in unpolluted urban forests, which may be beneficial for herbivores exploiting these plants. Kainulainen et al. (1993) showed that the amino acids glycine, ornithine, lysine and histidine in spruce seedlings had a significant negative correlation with distance from a pollution centre. Löyttyniemi \& Tulisalo (1972) have shown the importance of the amino acid content of the spruce needles for the fecundity of the two-spotted spider mite (Oliqonychus ununguis). Brodbeck \& Strong (1987) also pay attention to the importance of amino acids, pointing out how stress changes the composition of these essential compounds.

High total nitrogen values may indicate a better nutritional value. What is then the purpose of phenolics in needles? There seems to be invertebrate species benefitting and others suffering from secondary compounds like phenols and alkaloids, which are considered to act as plant defence mechanisms against pathogens and herbivores (Levin 1976). There are several phenolic compounds which probably have their own specific effects. Tannins and other phenols have been found to inhibit proteases and other digestive enzymes in the insect gut (Swain 1977). It has also been shown that their concentrations tend to increase in plant cells after damage caused by insects (Ryan \& Geen 1974). The secondary compounds are often effective even in small concentrations and thus only a minor increase may affect herbivores (Swain 1977). Kidd et al. (1990) observed the same seasonal variation in phenolic concentrations as in the present study, and they stated that any advantage caused by a higher amino acid concentration is outweighed by unfavourable phenolic and terpene compositions.

In our study there were no apparent between area differences in the total phenolics value. When the mean herbivore abundances and the concentration of total phenols were plotted against each other no significant correlations appeared although the trend was clear: when phenolic concentration increased the number of herbivores decreased. This trend became even more distinct when herbivore abundances were plotted against the phenolics/nitrogen ratio, which ratio was significantly smaller in the urban areas, indicating an elevated nitrogen and at the same time a low phenolics concentration. These results could mean that in areas where nitrogen concentration in the needles is high, indicating e.g. an elevated level of amino acids which could be used for feeding, and the phenolic concentration simultaneously is low, indicating a lack of compounds used for defense, favourable living conditions are available for certain herbivores. What causes these biochemical changes remains to be studied.

Acknowledgements. This work was supported by the Academy of Finland and by grants from the University of Oulu. Ritva Niemi, Pekka Vilkamaa, Tapio Lammes, Martin Meinander and Ole E. Heie helped us to identify some of the invertebrate species. Päivi Tanner and Arja Itämies were of great help in handling the branch and needle material. Comments by Samuel Panelius and Kari Heliövaara on the earlier version of the manuscript improved the text. 


\section{References}

Alstad, D. N., Edmunds, G. F. \& Weinstein, L. H. 1982 Effects of air pollutants on insect populations. - Ann. Rev. Entomol. 27: 369-384.

Anonymous 1986: Environmental policies in Finland. National report. Ministry of Environment. Environmental Protection and Nature Conservation Department. Serial D. 19/1986: 1-542.

Braun, S. \& Flückiger, W. 1984: Increased population of the aphid Aphis pomi at a motorway: Part 1. Field evaluation. - Environ. Poll. 39: 183-192.

Brodbeck, B. \& Strong, D. 1987: Amino acid nutrition of herbivorous insects and stress to host plants. - In: Barbosa, P. \& Schultz, J. C. (eds.), Insect outbreaks: 347-364. Academic Press San Diego, California.

Burns, R. E. 1963: Methods of tannin analysis for forage crop evaluation. - Georgia Agric. Exp. Stat. Techn. Bull. 32:4-14.

Dohmen, G. B. 1985: Secondary effects of air pollution: enhanced aphid growth. - Environ. Poll. 39: 227-234.

Dohmen, G. B., McNeill, S. \& Bell, J. N. B. 1984: Air pollution increases Aphis fabae pest potential. - Nature 307: 52-53.

Flückiger, W. \& Oertli, J. J. 1978: Observations of an aphid infestation on hawthom in the vicinity of a motorway. - Naturwissenschaften 65: 654-655.

Führer, E. 1985: Air pollution and the incidence of forest insect problem. - Zeitschr. Angew. Entomol. 99: 371-377.

Hain, F. P. 1987: Assessing impacts of a changing environment on forest productivity. - Proc. Plen. Sess. 9th North Amer. Forest Biol. Workshop 3: 93-102.

Heliövaara, K. 1986: Occurrence of Petrova resinella (Lepidoptera, Tortricidae) in a gradient of industrial air pollutants. - Silva Fennica 20: 83-90.

Heliövaara, K. \& Väisänen, R. 1986: Industrial air pollution and the pine bark bug, Aradus cinnamoneus (Heteroptera, Aradidae). — J. Appl. Entomol. 101: 469-478.

- 1990: Changes in population dynamics of pine insects induced by air pollution. - In: Watt, A. D., Leather, S. R., Hunter, M. D. \& Kidd, N. A. C. (eds.), Population dynamics of forest insects: 209-218. Athanaeum Press.

Holopainen, J. K., Mustaniemi, A., Kainulainen, P., Satka, H. \& Oksanen, J. 1993: Conifer aphids in an air-polluted environment. I. Aphid density, growth and accumulation of sulphur and nitrogen by scots pine and norway spruce seedlings. — Environ. Poll. 80: 185-191.

Jensen, T. S. 1988: Variability of Norway spruce (Picea abies L.) needles; performance of spruce sawflies (Gilpinia hercyniae Htg.) - Oecologia 77: 313-320.

Kainulainen, P., Satka, H., Mustaniemi, A., Holopainen, J. K. \& Oksanen, J. 1993: Conifer aphids in an airpolluted environment. II. Host plant quality. Environ. Poll. 80: 193-200.

Katayev, O. A., Golutvin, G. I. \& Selikhovkin, A. V. 1983: Changes in arthropod communities of forest biocoe- noses with atmospheric pollution. -- Entomol. Rev. 62: 20-29.

Kidd, N. A. C., Smith, S. D. J., Lewis, G. B. \& Carter, C. I. 1990: Interactions between host plant chemistry and the population dynamics of conifer aphides. - In: Watt, A. D., Leather, S. R., Hunter, M. D. \& Kidd, N. A. C. (eds.), Population dynamics of forest insects: 183-193. Athenaeum Press.

Knabe, W. 1976: Effects of sulphur dioxide on terrestrial vegetation. - Ambio 5 (5-6): 213-218.

Kramer, P. J. \& Kozlowski, T. T. 1979: Physiology of woody plants. - New York. $811 \mathrm{pp}$.

Laine, A., Orell, M. \& Itämies, J. 1990: Invertebrate fauna on Norwegian spruce (Picea abies) branches in northern Finland. - Entomol. Fennica 1: 193-199.

Lamppu, J. 1989: Männyn (Pinus sylvestris L.) paksuuskasvu Vantaan kalliometsissä ilmansaasteiden vaikutusten kannalta. [Breadth growth of pine (Pinus sylvestris L.) on the rocky forests of Vantaa as seen from the point of view of air pollution] (In Finnish) Vantaan kaupunki. Ympäristöasiainkeskus. Moniste/ Mimeogr. 7/89. 51 pp.

Larsson, S. 1989: Stressful times for the plant stress insect performance hypothesis. — Oikos 56: 277-283.

Levin, D. A. 1976: The chemical defences of plants to pathogens and herbivores. - Ann. Rev. Ecol. Syst. 7: 121-159.

Löyttyniemi, K. \& Tulisalo, U. 1972: Amino acid composition of the needles of four Norway spruce provenances and their effect on the occurrence of Oligonychys ununguis (Jacobi) (Acarina, Tetranychidae). - Ann. Entomol. Fennici 38: 122-126.

Mattson, W. J. \& Witter, J. A. 1990: Pollution induced changes in Forest insect relationships. - In: Burley, J. (ed.), IUFRO Congress, Montreal, Canada, Proceedings. Division 2: 152-163.

McNeill, S. \& Whittaker, J. B. 1990: Air pollution and treedwelling aphids. - In: Watt, A. D., Leather, S. R., Hunter, M. D. \& Kidd, N. A. C. (eds.), Population dynamics of forest insects: 195-208. Athanaeum Press.

Neuvonen, S., Lindgren, M. \& Suomela, J. 1987: The effects of artificial acid rain on the quality of leaves for aphids. (In Finnish with English summary) Aquilo Ser. Bot. 25: 109-114.

Opperman, T. A. 1985: Rinden- und holzbrütende Insekten an Immissiongeschädigten Fichten und Kiefern. Holz-Zentralbl. 14: 213-217.

Pietilä, M., Lähdesmäki, P., Pakonen, T., Laine, K., Saari, E. \& Havas, P. 1990: Effect of nitrogenous air pollutants on changes in protein spectra with the onset of winter in the leaves and shoots of the Bilberry (Vaccinium myrtillus L.). - Environ. Poll. 66: 103-116.

Ryan, C. A. \& Geen, T. R. 1974: Proteinase inhibitors in natural plant protection. - Rec. Adv. Phytochem. 8: 123-140.

Swain, T. 1977: Secondary compounds as protective agents. - Ann. Rev. Plant Physiol. 28: 479-501.

Swain, T. \& Hilles, W. E. 1956: The phenolic constituents of Prunus domestica 1. - The quantitative analysis of phenolic constituents. - J. Sci. Food. Agric. 10: 63-68. 
Tuovinen, J. P. 1989: Tarkennettu Euroopan rikkitase 1985. [A checked sulphur level of Europe] (In Finnish) In: Kulmala, A. \& Ryaboshapko, A. (eds.), Ilman pilaantuminen Itämeren alueella. Epäpuhtauksien kulkeutuminen ja niiden vaikutus ympäristöön. [Air pollution in the area of Baltic. Long distance transport of air impurities and their impact upon mileau] Leningrad Gidrometeoizat 1989: 1-256.
Villemant, C. 1981: Influence de la pollution atmospherique sur les populations d'aphides du pin sylvestre en foret de Roumane (Seine-maritime). - Environ. Poll. 24: 245-262.

Warrington, S. 1987: Relationship between $\mathrm{S}^{\wedge} 2$ dose and growth of the Pea aphid, Acyrthosiphon pisum, on peas. - Environ. Poll. 43: 155-162.

Table 2. The mean abundances of invertebrates (exx./ $000 \mathrm{~g}$ branch material) during the whole study period on urban (1-3) and rural (4-6) areas and the results of two-way ANOVA (NS=not significant, ${ }^{*}=p<0.05,{ }^{* *}=p<0.01$, $\left.{ }^{* * *}=p<0.001\right)$.

\begin{tabular}{|c|c|c|c|c|c|c|c|c|}
\hline \multirow{3}{*}{$\begin{array}{l} \\
\text { HERBIVORES } \\
\text { Acarina: }\end{array}$} & \multicolumn{3}{|c|}{ Urban areas } & \multicolumn{3}{|c|}{ Rural areas } & \multirow[b]{2}{*}{$F$} & \multirow[b]{2}{*}{$P$} \\
\hline & \multirow[t]{2}{*}{ Rusko } & \multicolumn{2}{|c|}{ Isko Linnanmaa } & \multicolumn{3}{|c|}{ Vittasuo Sanginjoki Taivalkoski } & & \\
\hline & & & & & & & & \\
\hline Tetranychidae & 1.9 & 0.2 & 1.5 & 0.0 & 0.0 & 0.0 & 3.31 & ** \\
\hline Ameronothrus dubinini Sitnikova & 140.9 & 377.0 & 169.7 & 71.9 & 7.2 & 4.8 & 24.18 & *** \\
\hline Diabterobates humeralis (Hermann) & 82.8 & 380.3 & 496.6 & 106.5 & 366.0 & 23.6 & 8.15 & 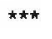 \\
\hline Ceratoppia bipilis (Hermann) & 0.4 & 781.8 & 327.7 & 91.6 & 37.4 & 9.4 & 32.46 & $* * \star *$ \\
\hline Camisia horrida (Hermann) & 9.7 & 51.9 & 43.0 & 11.8 & 5.3 & 1.5 & 10.98 & *** \\
\hline Oribatella calcarata Koch & 89.8 & 84.0 & 21.5 & 8.7 & 1.4 & 0.0 & 5.22 & $\star \star \star \star$ \\
\hline Trypochthonius sp. & 23.7 & 330.9 & 571.8 & 419.5 & 399.0 & 74.6 & 3.72 & $\star \star$ \\
\hline Unident. nymphal stage & 3.1 & 247.2 & 85.8 & 12.6 & 12.2 & 12.9 & 12.61 & $\star \star \star \star$ \\
\hline $\begin{array}{l}\text { Others } \\
\text { Psocoptera: }\end{array}$ & 12.3 & 12.1 & 14.4 & 58.5 & 46.8 & 14.2 & 3.55 & $\star \star$ \\
\hline Caecilius despaxi Badonnel & 4.3 & 0.4 & 1.6 & 2.6 & 4.9 & 0.8 & 2.91 & * \\
\hline C. burmeisteri Brauer & 0.4 & 1.5 & 1.1 & 0.2 & 5.2 & 0.1 & 7.94 & $\star \star \star \star$ \\
\hline Stenopsocus lachlani Kolbe & 0.0 & 0.4 & 1.0 & 0.4 & 0.7 & 2.3 & 2.13 & ns \\
\hline Other adults & 1.3 & 0.5 & 1.0 & 0.7 & 0.7 & 1.2 & 0.21 & ns \\
\hline $\begin{array}{l}\text { Juveniles } \\
\text { Heteroptera: }\end{array}$ & 10.8 & 12.9 & 6.4 & 19.2 & 16.9 & 13.1 & 1.32 & ns \\
\hline Lygus rugulipennis Poppius & 0.0 & 1.4 & 0.2 & 0.0 & 0.3 & 0.0 & 2.09 & ns \\
\hline Orthops rubricatus (Fallén) & 0.0 & 0.6 & 0.4 & 0.2 & 0.0 & 0.5 & 0.77 & ns \\
\hline Atractotomus magnicornis (Fallén) & 0.0 & 0.6 & 0.0 & 0.0 & 0.0 & 0.0 & 1.91 & ns \\
\hline $\begin{array}{l}\text { Others, juveniles } \\
\text { Homoptera: }\end{array}$ & 2.0 & 0.6 & 4.6 & 2.2 & 2.5 & 0.7 & 1.67 & ns \\
\hline Phenacoccus piceae (Löw) & 12.1 & 10.2 & 31.3 & 4.9 & 5.4 & 11.1 & 2.60 & * \\
\hline Elatobium abietinum (Walker) & 43.8 & 4.4 & 11.1 & 7.1 & 0.8 & 0.0 & 5.43 & *** \\
\hline Cinara sp. & 11.1 & 3.0 & 3.7 & 4.3 & 1.4 & 1.6 & 5.49 & *** \\
\hline $\begin{array}{l}\text { Adelges sp. } \\
\text { Thysanoptera: }\end{array}$ & 6.2 & 5.8 & 6.8 & 11.7 & 44.2 & 19.9 & 1.29 & ns \\
\hline Aeolothripidae & 28.2 & 10.4 & 12.6 & 24.0 & 10.4 & 0.3 & 3.76 & ** \\
\hline Phlaeothripidae & 7.0 & 14.3 & 19.1 & 6.8 & 8.0 & 7.8 & 4.92 & *** \\
\hline $\begin{array}{l}\text { Lepidoptera larvae: } \\
\text { Diptera: }\end{array}$ & 2.3 & 27.2 & 11.9 & 17.4 & 2.3 & 16.1 & 1.03 & ns \\
\hline Cecidomyidae & 4.3 & 2.9 & 1.8 & 3.0 & 3.0 & 4.0 & 1.03 & ns \\
\hline $\begin{array}{l}\text { larvae } \\
\text { Hymenoptera: }\end{array}$ & 15.7 & 19.8 & 44.5 & 30.4 & 16.9 & 14.4 & 4.79 & *** \\
\hline Pamphiliidae larva & 0.3 & 0.0 & 0.2 & 0.0 & 0.0 & 0.4 & 0.64 & ns \\
\hline Total: & 514 & 2328 & 1891 & 916 & 999 & 235 & 28.90 & $\star \star * *$ \\
\hline
\end{tabular}


Urban areas

Rural areas

Rusko Isko Linnanmaa Vittasuo SanginjokiTaivalkoski $\quad F \quad P$

CARNIVORES AND PARASITES

Phalangida:

Mitopus morio (Fabricius)

Acarina:

Parasitidae sp.

Cunaxidae sp.

Erythraeidae sp.

Araneae:

Theridiidae $\mathrm{sp}$.

Linyphiidae sp.

Others

Neuroptera:

Hemerobiidae larva

Hymenoptera:

Formicoidea

Others

Coleoptera:

Coccinellidae

Staphylinidae

larvae

$\begin{array}{rrrrrrrr}0.9 & 0.4 & 0.7 & 0.0 & 0.0 & 0.2 & 1.36 & \text { ns } \\ & & & & & & & \\ 92.6 & 46.0 & 68.9 & 68.8 & 28.4 & 12.9 & 9.25 & \text { *** } \\ 5.1 & 18.5 & 6.2 & 7.0 & 15.6 & 10.9 & 4.62 & \text { ***} \\ 0.0 & 0.0 & 0.0 & 0.0 & 4.5 & 0.0 & 1.29 & \text { ns } \\ & & & & & & & \\ 26.7 & 5.1 & 6.6 & 10.6 & 10.6 & 0.4 & 13.05 & \text { *** } \\ 51.9 & 81.5 & 96.3 & 53.4 & 31.2 & 21.1 & 24.55 & \text { *** } \\ 7.2 & 3.3 & 3.8 & 7.8 & 3.8 & 6.4 & 2.01 & \text { ns } \\ & & & & & & & \\ 1.1 & 0.4 & 0.6 & 0.2 & 0.7 & 1.9 & 1.58 & \text { ns } \\ & & & & & & & \\ 0.0 & 2.2 & 1.0 & 0.7 & 0.2 & 5.3 & 3.27 & * * \\ 6.3 & 6.8 & 7.3 & 5.7 & 4.3 & 4.3 & 0.84 & \text { ns } \\ & & & & & & & \\ 0.2 & 0.0 & 0.3 & 0.0 & 0.0 & 0.0 & 0.85 & \text { ns } \\ 0.7 & 0.2 & 0.7 & 1.3 & 0.2 & 0.2 & 2.41 & * \\ 0.0 & 1.6 & 0.4 & 0.5 & 0.2 & 0.2 & 2.41 & * \\ 193 & 165 & 193 & 156 & 100 & 65 & 24.27 & \text { *** }\end{array}$

OMNIVORES AND DECOMPOSERS

Collembola:

Entomobrya nivalis (Linnaeus)
Anurophorus septentrionalis Larissa
Others

568.3

\section{3}

325.6

517.8

$482.2 \quad 271.1$

$393.9 \quad 245.8$

$\begin{array}{rr}3.1 & 649.0 \\ 8.3 & 0.9\end{array}$

168.9

0.2

1.6

$5.04^{* \pi *}$

4.5

Coleoptera:

Total:

0.0

1.6

0.4

0.2

0.2

2.78 *

537

976

0.5

876

1.02 ns

ACCIDENTALS

Heteroptera:

Homoptera:

Psylloidea

Diptera:

Chironomidae

Sciaridae

Others

Hymenoptera:

Total:

\begin{tabular}{rrrrrrrr}
2.5 & 1.5 & 5.7 & 3.4 & 0.0 & 0.3 & 2.28 & * \\
1.3 & 6.5 & 5.6 & 0.9 & 13.1 & 0.6 & 3.39 & * \\
41.5 & 7.9 & 6.8 & 8.3 & 4.5 & 9.0 & 5.13 & *** \\
7.3 & 3.0 & 0.5 & 2.2 & 0.4 & 1.2 & 4.67 & *** \\
4.6 & 4.6 & 1.8 & 1.3 & 1.3 & 2.3 & 2.05 & ns \\
0.2 & 0.9 & 0.6 & 0.2 & 2.8 & 1.6 & 2.25 & $* *$ \\
57 & 25 & 21 & 16 & 22 & 15 & 8.34 & *** \\
1442 & 3110 & 3081 & 1778 & 1997 & 834 & 19.01 & $\ldots$ \\
\hline
\end{tabular}

ALL GROUPS 